\title{
Effects of Prosopis africana (Guill. \& Perr.) Taub. and Ficus mucoso Fi- calho ethanolic leaves extract in the control of Callosobruchus macula- tus (Fabricius, 1775) in stored cowpea
}

\author{
Tosin Damilola OJUYEMI ${ }^{1}$, Robert Omotayo UDDIN II ${ }^{1}$, Gbonjubola Victoria AWOLOLA ${ }^{2}$, Suleiman \\ MUSTAPHA $^{1,3}$ and Abdrahaman Adebowale LAWAL ${ }^{1}$
}

Received May 11, 2020; accepted September 02, 2021. Delo je prispelo 11. maja 2020, sprejeto 2. septembra 2021

Effects of Prosopis africana (Guill. \& Perr.) Taub. and Ficus mucoso Ficalho ethanolic leaves extract in the control of Callosobruchus maculatus (Fabricius, 1775) in stored cowpea

Abstract: The study investigated the effectiveness of Prosopis africana and Ficus mucoso ethanolic leave extract in the control of Callosobruchus maculatus infesting cowpea. Treatments were applied at different concentrations (10\%, $30 \%, 50 \%$, and $0 \%$ ) on cowpea. Five pairs of newly emerged adult C. maculatus were introduced into each treatment. The two botanicals were evaluated on the insecticidal effects it has on the insect and data were recorded on adult mortality, oviposition rate, larvae, pupae, and adult emergence, seed viability, and phytochemicals present in both botanicals. Results revealed that both treatments had insecticidal potentials, adversely reducing the number of eggs, larvae, and pupae of C. maculatus with P. africana having the highest mean mortality rate at $50 \%$ concentration. Observations further indicated that the botanicals had no negative effect on seed viability. The phytochemical analysis revealed the presence of some bioactive compounds such as terpenoids, flavonoids, alkaloids, saponin, steroids, and tannin, $P$. africana mostly rich in them than F. mucoso. Though both extracts were effective, $P$. africana performed better in the control of the bruchid beetle indicating plausible usefulness in sustainable pest management by smallholder farmers and consumers of cowpea in environments where the plants are in abundance.

Key words: Callosobruchus maculatus; cowpea; botanicals; storage entomology; plant-based insecticide; coleoptera
Učinki etanolnih izvlečkov iz listov vrst Prosopis africana (Guill. \& Perr.) Taub. in Ficus mucoso Ficalho na uravnavanje škodljivca Callosobruchus maculatus (Fabricius, 1775) v shranjenem zrnju kitajske vinje

Izvleček: V raziskavi so bili preučevani učinki etanolnih izvlečkov iz listov vrst Prosopis africana in Ficus mucoso na uravnavanje škodljivca Callosobruchus maculatus v semenu kitajske vinje. Obravnavanja so obsegala različne koncentracije izvlečka in sicer $10 \%, 30 \%, 50 \%$, in $0 \%$. Pet parov na novo izleglih odraslih osebkov škodljivca je bilo izpostavljenih izvlečkom $\mathrm{v}$ vseh obravnavanjih. Insekticidni učinki obeh rastlinskih vrst na hrošča so bili ovrednoteni glede na smrtnost odraslih osebkov, velikost ovipozicije, glede vplivov na ličinke in bube in izleganje odraslih osebkov. Ovrednoten je bil tudi učinek izvlečkov obeh vrst na vitalnost semen vinje in njihova kemična sestava. Izsledki so pokazali, da imata obe rastlinski vrsti insekticidni potencial, ker sta imeli negativni učinek na število jajčec, ličink in bub škodljivca, pri čemer je izvleček iz vrste $P$. africana povzročil največjo smrtnost pri $50 \%$ koncentraciji. Nadalje so opazovanja pokazala, da izvlečka obeh vrst nista imela negativnega učinka na vitalnost shranjenih semen vinje. Fitokemična analiza izvlečkov je odkrila prisotnost nekaterih bioaktivnih snovi kot so terpenoidi, flavonoidi, alkaloidi, saponini, steroidi, in tanini, pri čemer je bila vrsta P. africana bogatejša na njih kot vrsta $F$. mucoso. Čeprav so sta bila oba izvlečka učinkovita, je izvleček iz vrste $P$. africana deloval bolje pri uravnavanju populacije hrošča, kar kaže na verjetno koristnost uporabe pri trajnostnem obravnavanju škodljivcev pri malih kmetih in potrošnikih kitajske vinje $\mathrm{v}$ okoljih, kjer sta obe vrsti rastlin v izobilju.

Ključne besede: Callosobruchus maculatus; kitajska vinja; rastlinski pripravki; entomologija shranjevanja pridelkov; insekticidi na osnovi rastlin; hrošči

1 Department of Crop Protection, University of Ilorin, Ilorin, PMB 1515 Ilorin, Nigeria

2 Department of Industrial Chemistry, University of Ilorin, Ilorin, PMB 1515 Ilorin, Nigeria

3 Corresponding author, e-mail: juniorsuleiman78@gmail.com 


\section{INTRODUCTION}

Vigna unguiculata (L.) Walp (Cowpea), is an important legume crop in the tropics, and ensures the provision of plant-based protein for most people and also the fixation of nitrogen into the soils (Umeozor, 2005). Production of cowpea is limited by several abiotic and biotic factors, both in the field and in storage. Among the constraining biotic factors are insect pests (Swella \& Mushobozy, 2007) mainly due to infestation by the cowpea bruchid, Callosobruchus maculatus (Fabricius, 1775) (Coleoptera: Bruchidae) which is a cosmopolitan field-to-store pest, and has been ranked as the principal post-harvest pest of cowpea especially in the tropics. It causes substantial qualitative and quantitative losses, manifested by seed perforation, and reductions in mass, market value, and germination ability of seeds. In storage conditions, $100 \%$ infestation of cowpea, occurring within 3 to 5 months of storage, is not uncommon (Lale \& Mustapha, 2000).

Toxic residual insecticides have been used routinely for many years to control insect pests in stored grain. These insecticides are primarily organophosphorous and pyrethroid compounds (Arthur, 1996). Several methods have also been employed over the years to protect cowpea from damages by the pest, using chemical insecticides which is the most prevalent (Abdullahi et al., 2011). However, the use of chemical insecticides is fast becoming less desirable because of the resistance in major insects, regulatory restrictions on the use of insecticides, awareness of environmental pollution, the increasing cost of insecticides, erratic supplies, worker's safety and, consumer desire for a pesticide-free product, which has led to pest management specialists reappraising natural products for potential usage (Haghtalab et al., 2009).

Chemical methods are also directly or indirectly dangerous to the user and non-target organisms, destruction of beneficial organisms, residual toxicity, widespread environmental hazards, development of resistance by insect species, etc. are always in association with its usage (Oni \& Ileke, 2008; Oni, 2011). This necessitated the need for a safer alternative and sustainable control strategy. It is in this regard that extracts of plants have been thought of from different parts of the world. The method has been described as a cheaper eco-friendly and safer means of controlling insect pests of stored cowpea (Adedire et al., 2011).

Singh and Saratchandra (2005) reported that most plant species exhibit insect deterrent ability further indicative of the fact that some plant extracts can inhibit normal development in insects. Also, most of these plants can be acquired locally and freely and are easy to handle by smallholder farmers without any accruing adverse effects to man and the environment. In view of the increasing economic importance of cowpea and the intensity of damages due to insect pest infestation, an attempt was made to provide a safer method for the control of $C$. maculatus in stored grains using the plant extracts Prosopis africana and Ficus mucoso. Previously, there have been reports on the effectiveness of these plants genus in the control of pests and pathogens (Dangarembizi et al., 2012; Elaigwu et al., 2018; Zerihun \& Ele, 2018; Shinkafi \& Abdullahi, 2018) but without any scientific study targeted at investigating their potential effectiveness in curtailing the ruthless destruction by $C$. maculatus in stored seeds. The plants have promising potential to be considered as an alternative seed treatment to synthetic insecticides therefore the reason why this research work was initiated, to investigate the insecticidal activities of the two botanicals on the field-to-store insect pest. Furthermore, this research presents the first report on the use of $P$. africana and F. mucoso leave extracts in the control of the infamous cowpea weevil- C. maculatus.

\section{MATERIALS AND METHODS}

\subsection{SOURCE AND TYPE OF SEED}

The cowpea seeds used were the variety IT99K-573-1-1 which was obtained from the International Institute of Tropical Agriculture (IITA), Ibadan, Nigeria. The seeds were white in colour and medium in size. The cowpea seeds were stored in the freezer compartment of a refrigerator at $-17^{\circ} \mathrm{C}$ for four days before the seeds were used for the experiment.

\subsection{INSECT CULTURE}

Callosobruchus maculatus used for this study was obtained from Nigeria Stored Product Research Institute (NSPRI), Ilorin Kwara State. The cowpea variety IT99K-573-1-1 was used to maintain insect culture by placing seeds in a plastic container of medium size to culture the insect at room temperature $\left(22^{\circ} \mathrm{C}\right)$. Plastic containers used for insect culture were covered with muslin clothe at the top held with a rubber band to allow for ventilation. 


\subsection{COLLECTION AND PREPARATION OF PLANT MATERIALS}

Africana mesquites (Prosopis africana (Guill. \& Perr.) Taub.) and Sand paper (Ficus mucoso Ficalho) leaves were plucked within University of Ilorin premises. Leaves were washed and air-dried for 14 days in the open field of the faculty of agronomy pavilion. The dried leaves were ground using mortar and pestle and then passed through 90-micron mesh sieve to obtain a uniform powder.

\subsection{EXTRACTION OF PLANT MATERIALS}

Extraction of each plant material was carried out in the laboratory by soaking $500 \mathrm{~g}$ of each of the plant powder in 21 of ethanol for 72 hours with occasional stirring. The solution of each plant material was filtered using Whatman No. 1 filter paper. The extracts were concentrated using a rotary evaporator at a maximum temperature of $45^{\circ} \mathrm{C}$. The resulting crude extract was stored in a plastic container at room temperature until ready for use.

\subsection{METHODS OF PHYTOCHEMICAL SCREEN- ING}

Chemical tests were carried out on the ethanolic extracts for the qualitative determination of phytochemical constituents as described by Harborne (1973), Trease and Evans (1989), and Sofowora (1993).

\subsection{EXPERIMENTAL PROCEDURE}

The ethanolic leaf extracts of $P$. africana and $F$. mucoso were dissolved in distilled water to prepare solutions of different concentrations $(10,30$, and $50 \%$ w/v). $100 \mathrm{~g}$ of cowpea seeds were treated with $0.5 \mathrm{ml}$ of Prosopis africana and Ficus mucoso ethanolic extract in six replicates at different concentrations $(10,30,50 \%$ $\mathrm{w} / \mathrm{v})$ in transparent plastic containers $(7 \times 8 \mathrm{~cm})$ also, untreated seeds were included as a control $(0 \%)$. The plant extract was applied to the seed samples with a micro-syringe and was thoroughly mixed with a wooden spatula. The seeds were air-dried in the laboratory for 5 minutes before introducing five pairs of freshly emerged adults of Callosobruchus maculatus. To prevent escape and allow for ventilation, muslin cloth fastened with a rubber band were used to cover containers after applying the various treatments.

Adult weevil mortality was observed daily for 4 days at $24,48,72$, and 96 hours respectively and the number of dead weevils was counted and recorded. The insects were confirmed dead when there was no response to probing with a sharp entomological needle at the abdomen. Furthermore, to check for the emergence of new generation of the insect after applying the treatment on cowpea, a pointed forceps was used to pick five seeds at random from each replicate on the $4^{\text {th }}$, and $7^{\text {th }}$ day after infestation, and selected seeds were examined for eggs after dissection with a sharp blade and the dissected beans were examined for larvae and pupae. The pointed forceps were used to prevent damage of the egg on the seeds. The emergence of the first filial $\left(\mathrm{F}_{1}\right)$ adult generation was also observed from 28 to 32 days after infestation.

Seed viability test was carried out on ten randomly selected seeds from each replication with the various treatments and concentration levels at the end of the experiment using floatation and germination techniques. The floatation method was adopted from the technique described by Ehiagbonare and Enabulele (2007). The percentage viability of seeds was calculated using the following formula: . Here, $S=$ Number of treated seeds used per replicate. $\mathrm{SF}=$ Number of floating seeds per replicate.

The germination method was slightly modified from the technique described by Holly (2006). Cowpea seeds were placed on a petri dish already layered with dampened Whatman filter paper and left at room temperature $\left(26-28^{\circ} \mathrm{C}\right)$ for a period of 7 days during which time, samples were regularly checked for sprouting, and moisture was added to prevent complete dryness of the samples. The percentage viability of germinated cowpea seeds was recorded using the formula:

\subsection{STATISTICAL ANALYSIS}

Data were subjected to two-way analysis of variance (ANOVA). Where treatment means were significant, multiple comparisons of treatments was done using the Tukey's honestly significant difference test at $5 \%$ level of significance. All statistical analysis was done using the IBM SPSS version 26. 


\section{RESULTS}

\subsection{EFFECT OF BOTANICAL TYPES ON ADULT MORTALITY OF Callosobruchus maculatus}

Table 1 shows the effectiveness of the botanical types at different concentrations on the mortality of adult C. maculatus. At 24, 48, 72, and 96 hours after treatment (HAT) both P. africana and F. mucoso had the most significantly highest rate of C. maculatus mortality at the concentration level of $50 \%$ when compared to the control which had the least. Furthermore, the two botanical treatments at $30 \%$ also had effective control of the insect pest population from 24 to 96 HAT as presented in Table 1 . The mean number of insect mortality at the treatments concentration level of $10 \%$ indicated a slower rate of control in comparison to the concentration levels of 50 and $30 \%$.

The overall effects of the different botanical treatment are also indicated in Table 1. At 24, 48 and 72 HAT, $P$. africana had a significantly $(p<0.05)$ higher mortality rate of the mean $5.650 \pm 0.365,12.623 \pm 0.205$ and $13.359 \pm 0.025$ respectively when compared to F. mucoso which was lower at the mean numbers of $1.541 \pm 0.234$, $5.600 \pm 0.300$ and $10.863 \pm 0.044$ respectively. However, at 96 HAT, the leave extracts of P. africana and F. mucoso showed no significant difference of adult mortality of $C$. maculatus thus having the same effective level of control on the insect pest.

\subsection{EFFECT OF THE BOTANICAL TREATMENTS ON THE OVIPOSITION, LARVAE AND PU- PAE EMERGENCE OF C. maculatus}

Table 2 presents the activities of the botanical treatment in restricting the oviposition, larvae and pupae emergence of the insect pest. Post hoc analysis indicated the two different botanical treatments at $50 \%$ concentration to possess the least mean number of eggs and also larvae and pupae population. This was followed by the concentration rate of $30 \%$ only for seeds treated with P. africana. F. mucoso had no significant differences with the control at the concentration rate of $30 \%$ and $10 \%$ in all the various early life stages in Table 2.

In total, the control had the most numbers of eggs, larvae and pupae of the insect pest. There was no significant difference in the two botanical treatments in the number of eggs laid by the pest. Furthermore, seeds that were treated with $P$. africana had the least larvae and pupae emergence compared to F. mucoso and the control (Table 2).

Table 1: Effect of P. africana and F. mucoso concentrations on adult mortality of C. maculatus

\begin{tabular}{|c|c|c|c|c|c|}
\hline \multirow[b]{2}{*}{ Botanical type } & \multirow[b]{2}{*}{ Concentrations } & \multicolumn{4}{|c|}{ Adult mortality rate (HAT) } \\
\hline & & 24 & 48 & 72 & 96 \\
\hline \multirow[t]{3}{*}{ P. africana } & $10 \%$ & $0.000 \pm 0.000^{c}$ & $6.670 \pm 1.620^{c}$ & $13.33 \pm 0.590^{\mathrm{b}}$ & $16.670 \pm 0.033^{b}$ \\
\hline & $30 \%$ & $10.00 \pm 2.000^{\mathrm{ab}}$ & $20.00 \pm 3.452^{\mathrm{ab}}$ & $20.00 \pm 3.452^{\mathrm{a}}$ & $16.670 \pm 0.740^{\mathrm{b}}$ \\
\hline & $50 \%$ & $13.331 \pm 0.612^{\mathrm{a}}$ & $23.33 \pm 4.213^{\mathrm{a}}$ & $20.00 \pm 3.562^{\mathrm{a}}$ & $26.67 \pm 1.111^{\mathrm{a}}$ \\
\hline \multirow[t]{3}{*}{ F. mucoso } & $10 \%$ & $0.000 \pm 0.000^{c}$ & $6.670 \pm 1.620^{c}$ & $6.670 \pm 1.620^{\mathrm{d}}$ & $16.671 \pm 0.323^{\mathrm{b}}$ \\
\hline & $30 \%$ & $6.670 \pm 1.020^{\mathrm{b}}$ & $16.67 \pm 0.321^{\mathrm{ab}}$ & $16.671 \pm 0.321^{\mathrm{ab}}$ & $16.671 \pm 0.033^{\mathrm{b}}$ \\
\hline & $50 \%$ & $13.330 \pm 0.723^{\mathrm{a}}$ & $20.000 \pm 3.521^{\mathrm{ab}}$ & $20.00 \pm 3.510^{\mathrm{a}}$ & $23.33 \pm 2.271^{\mathrm{ab}}$ \\
\hline Control & 0.0 & $0.000 \pm 000^{c}$ & $0.000 \pm 0.000^{\mathrm{d}}$ & $0.000 \pm 0.000^{\mathrm{e}}$ & $3.330 \pm 1.730^{c}$ \\
\hline \multicolumn{6}{|c|}{ Total effect of the botanical treatments } \\
\hline P. africana & & $5.650 \pm 0.36^{5 a}$ & $12.623 \pm 0.205^{\mathrm{a}}$ & $13.359 \pm 0.025^{\mathrm{a}}$ & $15.848 \pm 0.022^{a}$ \\
\hline F. mucoso & & $1.541 \pm 0.234^{\mathrm{b}}$ & $5.600 \pm 0.300^{\mathrm{b}}$ & $10.863 \pm 0.044^{\mathrm{b}}$ & $15.467 \pm 0.404^{\mathrm{a}}$ \\
\hline Control & & $0.000 \pm 0.000^{c}$ & $0.000 \pm 0.000^{c}$ & $0.000 \pm 0.000^{c}$ & $0.000 \pm 0.000^{\mathrm{b}}$ \\
\hline
\end{tabular}

Values with the same letter $(\mathrm{s})$ in the same column are not significantly different from each other at $p<0.05$, HAT $=$ Hour after treatment 
Table 2: Effect of botanical types on the early life stages of C. maculatus

\begin{tabular}{|c|c|c|c|c|}
\hline & & \multicolumn{3}{|c|}{ Life stages } \\
\hline Treatment & Conc. $(\%)$ & Oviposition & Larvae & Pupae \\
\hline \multirow[t]{3}{*}{ P. africana } & 10 & $4.333 \pm 2.733^{\mathrm{abc}}$ & $2.000 \pm 0.632^{\mathrm{bc}}$ & $2.667 \pm 1.366^{\mathrm{ab}}$ \\
\hline & 30 & $2.500 \pm 0.547^{\mathrm{bcd}}$ & $2.000 \pm 1.265^{\mathrm{bc}}$ & $1.833 \pm 1.169^{\mathrm{ab}}$ \\
\hline & 50 & $1.333 \pm 0.516^{\mathrm{d}}$ & $0.833 \pm 0.753^{c}$ & $1.000 \pm 0.894^{\mathrm{b}}$ \\
\hline \multirow[t]{3}{*}{ F. mucoso } & 10 & $5.000 \pm 1.673^{\mathrm{ab}}$ & $4.000 \pm 1.265^{\mathrm{a}}$ & $3.500 \pm 1.049^{\mathrm{a}}$ \\
\hline & 30 & $3.167 \pm 0.983^{\mathrm{abcd}}$ & $2.500 \pm 1.517^{\mathrm{abc}}$ & $2.500 \pm 1.643^{\mathrm{ab}}$ \\
\hline & 50 & $1.833 \pm 0.753^{\mathrm{cd}}$ & $1.667 \pm 0.516^{\mathrm{bc}}$ & $2.167 \pm 0.753^{\mathrm{ab}}$ \\
\hline Control & 0 & $5.333 \pm 1.751^{\mathrm{a}}$ & $4.333 \pm 1.366^{\mathrm{a}}$ & $3.667 \pm 1.211^{\mathrm{a}}$ \\
\hline \multicolumn{5}{|c|}{ Total effect of the botanical treatments } \\
\hline P. africana & & $2.722 \pm 1.994^{b}$ & $1.611 \pm 1.036^{c}$ & $1.833 \pm 1.294^{\mathrm{b}}$ \\
\hline F. mucoso & & $3.333 \pm 1.749^{\mathrm{b}}$ & $2.722 \pm 1.487^{\mathrm{b}}$ & $2.722 \pm 1.274^{\mathrm{ab}}$ \\
\hline Control & & $5.500 \pm 1.567^{\mathrm{a}}$ & $3.833 \pm 1.403^{\mathrm{a}}$ & $3.583 \pm 1.443^{\mathrm{a}}$ \\
\hline
\end{tabular}

Values with the same letter (s) in the same column are not significantly different from each other at $p<0.05$

Table 3: Effect of botanical treatment on emergence of C. maculatus adults

\begin{tabular}{|c|c|c|c|c|c|c|}
\hline \multirow[b]{2}{*}{ Treatment } & \multirow[b]{2}{*}{ Conc. (\%) } & \multicolumn{5}{|c|}{ Adult emergence (DAT) } \\
\hline & & 28 & 29 & 30 & 31 & 32 \\
\hline \multirow[t]{3}{*}{ P. africana } & 10 & $2.500 \pm 2.168^{\mathrm{abc}}$ & $2.833 \pm 2.317^{b c}$ & $3.333 \pm 2.582^{\mathrm{ab}}$ & $3.833 \pm 0.983^{\mathrm{ab}}$ & $3.500 \pm 2.258^{\mathrm{abc}}$ \\
\hline & 30 & $1.667 \pm 1.633^{\mathrm{bc}}$ & $2.333 \pm 2.338^{c}$ & $4.333 \pm 1.751^{\mathrm{ab}}$ & $2.333 \pm 1.033^{\mathrm{b}}$ & $1.500 \pm 1.378^{c}$ \\
\hline & 50 & $0.333 \pm 0.817^{c}$ & $0.333 \pm 0.516^{c}$ & $1.667 \pm 1.211^{\mathrm{b}}$ & $1.667 \pm 0.817^{\mathrm{b}}$ & $1.333 \pm 0.516^{c}$ \\
\hline \multirow[t]{3}{*}{ F. mucoso } & 10 & $4.167 \pm 1.169^{\mathrm{ab}}$ & $5.833 \pm 2.483^{\mathrm{ab}}$ & $4.000 \pm 0.632^{\mathrm{ab}}$ & $4.500 \pm 2.509^{\mathrm{ab}}$ & $2.833 \pm 1.169^{a b c}$ \\
\hline & 30 & $2.500 \pm 2.509^{\mathrm{abc}}$ & $3.333 \pm 2.422^{\mathrm{bc}}$ & $3.500 \pm 1.517^{\mathrm{ab}}$ & $3.167 \pm 1.941^{\mathrm{ab}}$ & $2.167 \pm 1.472^{\mathrm{bc}}$ \\
\hline & 50 & $1.667 \pm 2.066^{\mathrm{bc}}$ & $2.333 \pm 1.211^{\mathrm{c}}$ & $4.667 \pm 1.211^{\mathrm{ab}}$ & $3.500 \pm 1.049^{\mathrm{ab}}$ & $2.667 \pm 1.506^{\mathrm{abc}}$ \\
\hline Control & 0 & $5.167 \pm 1.722^{\mathrm{a}}$ & $6.667 \pm 1.366^{\mathrm{a}}$ & $6.333 \pm 2.582^{\mathrm{a}}$ & $5.833 \pm 2.041^{\mathrm{a}}$ & $4.833 \pm 1.169^{\mathrm{a}}$ \\
\hline \multicolumn{7}{|c|}{ Total effect of the botanical treatments } \\
\hline P. africana & & $1.500 \pm 1.791^{\mathrm{b}}$ & $1.833 \pm 2.121^{\mathrm{c}}$ & $3.111 \pm 2.139^{\mathrm{b}}$ & $2.611 \pm 1.289^{\mathrm{b}}$ & $2.111 \pm 1.779^{\mathrm{b}}$ \\
\hline F. mucoso & & $2.778 \pm 2.157^{\mathrm{b}}$ & $3.833 \pm 2.503^{\mathrm{b}}$ & $4.056 \pm 1.211^{\mathrm{b}}$ & $3.722 \pm 1.904^{\mathrm{ab}}$ & $2.556 \pm 1.338^{\mathrm{b}}$ \\
\hline Control & & $5.167 \pm 1.801^{\mathrm{a}}$ & $6.333 \pm 1.497^{\mathrm{a}}$ & $5.750 \pm 2.179^{\mathrm{a}}$ & $4.750 \pm 2.379^{\mathrm{a}}$ & $4.583 \pm 1.311^{\mathrm{a}}$ \\
\hline
\end{tabular}

Values with the same letter $(s)$ in the same column are not significantly different from each other at $p<0.05, \mathrm{DAT}=\mathrm{Days}$ after treatment 


\subsection{EFFECT OF THE BOTANICAL TREATMENT ON THE EMERGENCE OF ADULT C. macula- tus $\mathrm{F}_{1}$ PROGENY}

Results in Table 3 indicated both $P$. africana and F. mucoso leaves extract treatment at $50 \%$ to have significantly $(p<0.05)$ reduced the population of newly emerging C. maculatus adults at 28 and 29 days after treatment (DAT) when compared to the control. Subsequent observations of the treatment effects on 30, 31 and 32 DAT revealed seeds treated with P. africana at $50 \%$ concentration had the lowest number of adults that emerged than the rest of the treatments and the control as shown in Table 3.

The overall treatment effects of the two botanicals on the emergence of $\mathrm{F} 1$ progeny of $C$. maculatus adults is presented in Table 3. At 28, 30 and 32 DAT, there was no significant difference between P. africana and F. mucoso leaves extract treatment which had the least population of the insect pest compared to the control. At 29 and 31 DAT, it was observed that overall treatment effect of $P$. africana had the least F1 progeny emergence than the F. mucoso treated seeds and the control (Table $3)$.

3.4 EFFECT OF THE BOTANICAL TREATMENT ON COWPEA SEED VIABILITY

The results for floatation and germination test to check for cowpea seed viability after treatment with $P$. africana and $F$. mucoso leaves extract is presented in Table 4 . Overall, there was no significant $(p>0.05)$ differences detected between the various treatment groups and their concentrations in both the floatation and germination test carried out.

On the other hand, the total effects of the treatments indicated a significant difference with the control $(7.167 \pm 1.115)$ having the least seed viability in the floatation test in comparison to both the P. africana $(8.833 \pm 1.505)$ and $F$. mucoso $(8.778 \pm 1.263)$ treated seeds which had no difference (Table 4$)$. The germination test indicated no significant $(\mathrm{P}>0.05)$ difference in seed viability considering the total effect of the botanical treatments as inferred in Table 4.

Table 5: Qualitative analysis of phytochemical composition of ethanolic leave extracts of Prosopis africana and Ficus mucoso

\begin{tabular}{lll}
\hline Phytochemicals & Prosopis africana & Ficus mucoso \\
\hline Saponins & + & + \\
Tannins & ++ & ++ \\
Flavonoids & ++ & - \\
Terpenoids & +++ & - \\
Alkaloids & ++ & + \\
Steroids & + & ++ \\
\hline
\end{tabular}

Key: - $=$ not present, $+=$ present in very small concentration, $++=$ present in moderately high concentration, $+++=$ present in very high concentration

Table 4: Effects of botanical treatment on seed viability

\begin{tabular}{|c|c|c|c|}
\hline \multirow[b]{2}{*}{ Treatment } & \multirow[b]{2}{*}{ Conc. $(\%)$} & \multicolumn{2}{|c|}{ Seed viability (\%) } \\
\hline & & Floatation & Germination \\
\hline \multirow[t]{3}{*}{ P. africana } & 10 & $8.500 \pm 1.378^{\mathrm{ab}}$ & $6.333 \pm 1.751^{\mathrm{a}}$ \\
\hline & 30 & $8.333 \pm 2.066^{\mathrm{ab}}$ & $6.000 \pm 1.789^{a}$ \\
\hline & 50 & $9.667 \pm 0.516^{\mathrm{a}}$ & $4.000 \pm 1.414^{\mathrm{a}}$ \\
\hline \multirow[t]{3}{*}{ F. mucoso } & 10 & $8.000 \pm 1.673^{\mathrm{ab}}$ & $4.667 \pm 2.160^{\mathrm{a}}$ \\
\hline & 30 & $9.167 \pm 0.753^{\mathrm{ab}}$ & $5.667 \pm 2.422^{a}$ \\
\hline & 50 & $9.167 \pm 0.983^{\mathrm{ab}}$ & $4.500 \pm 1.378^{\mathrm{a}}$ \\
\hline Control & 0 & $7.500 \pm 1.049^{\mathrm{ab}}$ & $5.000 \pm 2.168^{\mathrm{a}}$ \\
\hline \multicolumn{4}{|c|}{ Total effect of the botanical treatments } \\
\hline P. africana & & $8.833 \pm 1.505^{\mathrm{a}}$ & $5.444 \pm 1.886^{a}$ \\
\hline F. mucoso & & $8.778 \pm 1.263^{\mathrm{a}}$ & $4.944 \pm 1.984^{\mathrm{a}}$ \\
\hline Control & & $7.167 \pm 1.115^{\mathrm{b}}$ & $6.250 \pm 2.179^{a}$ \\
\hline
\end{tabular}

Values with the same letter (s) in the same col 


\subsection{QUALITATIVE ANALYSIS OF PHYTO- CHEMICAL COMPOSITION OF ETHANOLIC LEAVES EXTRACT OF BOTANICALS}

Table 5 shows the qualitative analysis of phytochemical composition of ethanolic leaves extract of the two botanicals. The result of the phytochemical screening indicated that saponins were present in very small concentrations in Prosopis africana and Ficus mucoso. Tannin was found to be present in moderately high concentrations in Prosopis africana and Ficus mucoso. Flavonoids were also found to be present in moderately high concentration in P. africana and not present in $F$. mucoso. Terpenoid was found to be present in very high concentration in P. africana and not present in F. mucoso. Furthermore, alkaloids were present in moderately high concentration in $P$. africana while in very small concentration in F. mucoso. Lastly, steroid was indicated in very small concentration in P. africana and present in moderately high concentration in F. mucoso as shown in Table 5 .

\section{DISCUSSION}

Several plant products have been studied to possess insecticidal properties against a wide range of insects, particularly agricultural pests (Abdullahi \& Muhammad, 2004; Bishnu \& Weisman, 2005; Swella \& Mushobozy, 2007; Ajayi, 2007; Raja \& William, 2008; Alan et al., 2009; Aly \& Sahar, 2010). Extracts from such a plant have a natural tendency to break down rapidly and are environmentally safer as they produce no residue effect (Islam, 2006). Herein in this work, we presented the first evidence-based trials on the bioactive potential of two different plant ethanolic leave extracts namely $P$. africana and F. mucoso in the control of $C$. maculatus infesting stored cowpea. The results obtained revealed that the extract of the two botanicals caused a significant rate of mortality on the insect pest. However, the cowpea seeds treated with $P$. africana leaves extract recorded the highest mean mortality of adult C. maculatus compared to F. mucoso, especially at the highest treatment concentration. The insecticidal effect of the plants ethanolic extracts on C. maculatus in the treated cowpea seeds might be a result of direct contact. Most insects breathe by means of trachea which usually open at the surface of the body through spiracles, the extract mixed with the seeds might have blocked these spiracles thereby leading to suffocation and death of the insects (Adedire \& Akinkurolele, 2005; Rahman \& Talukder, 2006; Akinkurolele et al., 2006).

On the oviposition and emergence of a new gen- eration of C. maculatus (larvae, pupae stage, and adult emergence) both P. africana and F. mucoso leave extracts were significantly effective in suppressing the population of the insect especially when the dosage of the extracts was increased (although, seed lots treated with $P$ africana were observed to have had the least population of the insect pest). This means that the plants leave extracts had insecticidal properties that inhibited egg-laying, larvae, pupation, and the emergence of new adults of the insect, the repellant effects by the plant materials inactivated the insect pest (Lale \& Ofuya, 2001; Adedire et al., 2011; Ileke \& Olotuah, 2012). Similar work using other plant materials was also reported by Lale \& Ofuya (2001) who stated that botanicals with toxic constituents are effective in the suppression of the various life stages of insect pests, though, he did not work on $P$. africana and F. mucoso, this work shows that the two botanicals could be applied in restricting the various early life stages of $C$. maculatus.

The phytochemical analysis of the two botanicals revealed that they contained bioactive compounds such as alkaloids, steroids, saponins, tannins, flavonoids, and terpenoids with $P$. africana containing the vast majority of the compounds in considerable amounts when compared to F. mucoso. The secondary plant metabolites may be responsible for the insecticidal properties of the leave extracts (Kabaru \& Gichia, 2009). Iwuala et al. (1981) stated that aromatic compounds such as terpenoids, flavonoids, and saponins have ovicidal, toxic, and deterrent effects on coleopterous insect pests infesting stored products. The presence of terpenoids in $P$. africana indicated that the plant extract could act as an antifeedant, growth disruptor and possessed considerable toxicity toward insects' pests of stored seeds (Khalid et al., 1989). Okwu (2001) also stated that steroidal compounds which were more in F. mucoso play importance in pharmacy due to their relationship with such compounds as sex hormones and as such may be also responsible for disrupting the life cycle of the insect pest. The phytochemicals richly identified in $P$. africana leaves extract may be attributed to the reason it has the highest mean mortality rate and lowest oviposition and emergence of the insect pest when compared to F. mucoso.

Seed viability test indicated no negative effects of the two botanical treatments on cowpea even at increasing application rate of the treatment which did not differ from seeds that were not treated (the control) hence safe for usage on stored seeds before planting. It is conceivable to infer here that both $P$. africana and F. mucoso plant extracts offered a cheaper and sustainable alternative to synthetic insecticides (Mukanga et 
al., 2010) in the control of C. maculatus infesting stored cowpea seeds.

\section{CONCLUSION}

Many studies have addressed the insecticidal efficacy of some plant species. Prosopis africana and Ficus mucoso ethanolic leaves extract were evaluated for insecticidal activity in this study. This research indicated that the plant material may be suitable for developing plant-based insecticides which are biodegradable and ecologically friendly. This could be further adopted by smallholder farmers in the usage against major storage pests of cowpea. P. africana leaves extract had more insecticidal potential compared to F. mucoso, the latter could still be utilized especially in environments where they are growing in abundance if the former is lacking and as such could be integrated with other pest management approach in suppressing insect pests.

\section{REFERENCES}

Abdullahi, N., Majeed, Q. \& Oyeyi, T. I. (2011). Studies on the efficacy of Vittallaria paradoxa seed oil on the oviposition, hatchability of eggs and emergence of Callosobruchus maculatus (F.) (Coleoptera: Bruchidae) on treated cowpea seed. Journal of Entomology, 8, 391-397. https:/doi. org/10.3923/je.2011.391.397

Abdullahi, Y.M. \& Muhammad, S (2004). Effects of some plant powders on cowpea weevil Callosobruchus maculatus during storage. African Journal of Biotechnology, 3(1), 67-70.

Adedire, C, Akinkurolere, R. O. \& Ajayi, O. O. (2011). Susceptibility of some maize cultivars in Nigeria to infestation and damage by maize weevil, Sitophilus zeamais (Motsch) (Coleoptera: Curculionidae). Nigerian Journal of Entomology, 28, 55-63.

Adedire, C. O. \& Akinkurolele, R. O. (2005). Bioactivity of four plant extract on coleopterous pests of stored cereals and grain legumes in Nigeria. Zoological Research, 26, 243-249.

Ajayi, F. A. (2007). Effect of grain breakage and application of edible oils to protect pearl millet, Pennisetum glaucum (L.) R. Br., against infestation by adult Tribolium castaneum (Herbst.) (Coleoptera: Tenebrionidae) in Lafia, Nigeria. Nigerian Journal of Entomology, 24, 107-113.

Ajayi, F. A., Wintola, H. U. (2006). Suppression of the cowpea bruchid (Callosobruchus maculatus (F.) infesting stored cowpea (Vigna unguiculata (L.) Walp.) seeds with some edible plant product powders. Pakistani Journal of Biological Sciences, 9(8), 1454-1459. https://doi.org/10.3923/ pjbs.2006.1454.1459

Akinkurolele, R. O., Adedire, C. O. \& Odeyemi, O. O. (2006). Laboratory evaluation of the toxic properties forest $\mathrm{An}$ chomanes difformis against pulse beetles Callosobrun- chus maculatus. Insect Science, 13, 25-29. https://doi. org/10.1111/j.1744-7917.2006.00064.x

Alan, C, Dobson, H, Grzywacz, D, Hodges, R, Orr, A. \& Stevenson, P. (2009). Review of pre- and post-harvest pest management for pulses with special reference to Eastern and Southern Africa. Natural Resources Institute prepared for and funded by McKnight Foundation, Collaborative Crops Research Program.

Aly, S. D., Sahar, I. A. (2010). Efficacy of spearmint oil and powder as alternative of chemical control against Callosobruchus maculatus in Cowpea Seeds. Egyptian Academic Journal of Biological Sciences, 2(1), 53-61. https://doi. org/10.21608/eajbsf.2010.17463

Arthur, F. (1996). Grain protectants: Current status and prospects for the future. Journal of Stored Products Research, 32, 293-302. https://doi.org/10.1016/S0022-474X(96)00033-1

Bishnu, C. \& Weisman, Z. (2005). Larvicidal effects of aqueous extracts of Balanites aegyptiaca (desert date) against the larvae of Culex pipiens mosquitoes. African Journal of Biotechnology, 4(11), 1351-1354.

Dangarembizi, R., Erlwanger, K., Moyo, D. \& Chivandi, E. (2012). Phytochemistry, pharmacology and ethnomedicinal uses of Ficus Thonningii (Blume Moraceae): A Review. African journal of traditional, complementary, and alternative medicines: AJTCAM / African Networks on Ethnomedicines, 10. 203-212. 10.4314/ajtcam.v10i2.4. https://doi. org/10.4314/ajtcam.v10i2.4

Ehiagbonare, J. E. \& Enabulele, S. A. (2007). Effect of storage regime, presorting treatments, light and dark on seed germination of Chrysophylluum delevoyi (De Wild). Nigerian Journal of Applied Science, 25, 151-156.

Elaigwu, M., Oluma, H.O.A. \& Onekutu, A. (2018). Phytochemical and antifungal activity of leaf extracts of Prosopis africana and Anacardium occidentale against Macrophomina root rot of Sesamum indicum L. in Benue State, Central Nigeria. Journal of Geoscience and Environment Protection, 6, 66-76. https://doi.org/10.4236/gep.2018.67005

Haghtalab, N., Shayesteh, N. \& Aramideh, S. (2009). Insecticidal efficacy of castor and hazelnut oils in stored cowpea against Callosobruchus maculatus (F.) (Coleoptera: Bruchidae). Journal of Biological Sciences, 9, 175-179. https://doi. org/10.3923/jbs.2009.175.179

Harborne, J. B. (1973). Phytochemical methods: A guide to modern techniques of plant analysis. Chapman and Hall Ltd, London; Pp. 279.

Holly, S. K. (2006). Seed Germination. Library, Gardening in Western Washington. Presented by WSU Extension.

Ileke, K. D. \& Olotuah, O. F. (2012). Bioactivity of Anacardium occidentale (L) and Allium sativum (L) powders and oils extracts against cowpea bruchid, Callosobruchus maculatus (Fab.) (Coleoptera: Chrysomelidae). International Journal of Biology, 4(1), 23-28. https://doi.org/10.5539/ ijb.v4n1p96

Islam, Shahidul (2006). Sweetpotato (Ipomea batatas L.) leaf: its potential effect on human health and nutrition. Journal of Food Science, 71, 13-21. https://doi. org/10.1111/j.1365-2621.2006.tb08912.x

Iwuala, M. O. E., Osisiogwu, I. U. W. \& Agbakwuru E. U. P. (1981). Dennetia oil, a potential new insecticide: Tests 
with adults and nymphs of Periplanata america and $\mathrm{Zo}$ nocerus variegatus. Journal of Economic Entomology, 74, 249-252. https://doi.org/10.1093/jee/74.3.249

Kabaru, M. \& Gichia, L (2009). Insecticidal activity of extracts derived from different parts of the mangrove tree Rhizophora mucronata (Rhizophoraceae) Lam. against three arthropods. African Journal of Science and Technology, 2, 10. https://doi.org/10.4314/ajst.v2i2.44668

Khalid, Sami, Duddeck, Helmust \& Gonzalez-Sierra, Manuel (1981). Isolation and characterization of an antimalarial agent of the neem tree Azadirachta indica. Journal of natural products, 52, 922-6. https://doi.org/10.1021/ np50065a002

Lale, N. E. S \& Mustapha, A. (2000). Potential of combining neem (Azadirachta indica A. Juss.) seed oil with varietals resistance for the management of the cowpea bruchid, Callosobruchus maculatus (F.). Journal of Stored Products Research, 36, 215-222. https://doi.org/10.1016/S0022474X(99)00035-1

Lale, N.E.S., and Ofuya, T.I. (2001). Overview of pest problems and control in the tropical storage environment. In: Ofuya, T.I. and Lale, N.E. S. (eds.) Pests of Stored Cereals and Pulses in Nigeria: Biology, Ecology and Control. Dave Collins Publications, Akure, Nigeria. pp. 1-23.

Okwu, D. E (2001). Evaluation of chemical composition spices and flavoring agents. Global Journal of pure and Applied Science, 7, 455-459. https://doi.org/10.4314/gjpas.v7i3.16293

Oni, M. O \& Ileke, K. D. (2008). Fumigant toxicity of four botanical plant oils on survival, egg laying and progeny development of the dried yam beetle, Dinoderus porcellus (Coleoptera: Bostrichidae) Ibadan. Journal of Agricultural Research, 4(2), 31-36.

Oni, M. O. (2011). Evaluation of seeds and fruit powder of Capsicum annum and C. frutescens for control of Callosobruchus maculatus (Fab.) in stored cowpea and Sitophilus zeamais in stored maize. International Journal of Biology, 3(2), 185-188. https://doi.org/10.5539/ijb.v3n2p185

Rahman, A. \& Talukder, F. A. (2006). Bio efficacy of some plant derivatives that protect grain against the pulse beetle, $\mathrm{Cal}$ losobruchus maculatus. Journal of Insect Science, 6. 3. https:// doi.org/10.1673/1536-2442(2006)6[1:BOSPDT]2.0.CO;2

Raja, M. \& William S. J. (2008). Impact of volatile oils of plant against cowpea beetle Callosobruchus maculatus (Fabr) (Coloeoptera: Bruchidae). International Journal Integrative Biology, 2(1), 62-64.

Singh R. N. and Saratchandra B (2005). The development of botanical products with special reference to Seri-ecosystem. Caspian Journal of Environmental Sciences, 3(1), 1-8.

Shinkafi, S. A \& Abdullahi, H. (2018). Antifungal activity and phytochemical analysis of Ficus sycomorus leaf extract on Malassezia glubosa. Advances in Plants and Agricultural Research, 8(6), 432-436. https://doi.org/10.15406/ apar.2018.08.00362

Sofowora, A. (1993) Medicinal Plants and Traditional Medicine in Africa. Spectrum Books Ltd., Ibadan, 191-289.

Swella, G. B. \& Mushobozy, D. M. K. (2007). Evaluation of the efficacy of protectants against cowpea bruchids (Callosobruchus maculatus (F.)) on cowpea seeds (Vigna unguiculata (L.) Walp.). Plant Protection Science, 43(2), 68-72. https://doi.org/10.17221/2256-PPS

Trease, G. E. \& Evans, W. C. (1989). Pharmacognosy. Bailliere Tindall.

Umeozor, O. C. (2005). Effect of the infection of Callosobruchus maculatus (Fab.) on the weight loss of stored cowpea (Vigna unguiculata (L.) Walp). Journal of Applied Sciences and Environmental Management, 9(1), 169-172.

Zerihun M, Ele E (2018). Insecticidal activities of leaf, seed and stem bark extracts of Prosopis juliflora against the cotton (Aphis gossypii Glover) aphid. Academic Research Journal of Agricultural Science Research, 6(3), 202-221. 